\title{
Pengaruh Gaya Hidup dan Promosi Terhadap Kepuasan Konsumen EDC (Electronic Data Capture) Yokke yang Dimediasi Oleh Keputusan Pembelian" (Studi Kasus Pengguna EDC Yokke PT. Mitra Transaksi Indonesia)
}

\section{Jhoni Hendra Sitepu}

Program Studi Magister Manajemen, Universitas Muhammadiyah Sumatera Utara

\section{Hazmanan Khair}

Program Studi Magister Manajemen, Universitas Muhammadiyah Sumatera Utara

\section{Fajar Pasaribu}

Program Studi Magister Manajemen, Universitas Muhammadiyah Sumatera Utara

Koresponden: fajarpasaribu@umsu.ac.id

\begin{abstract}
Abstrak The purpose of this study was to examine and analyze Lifestyle and Promotion of Consumer Satisfaction at EDC (Electronic Data Capture) Yokke which is mediated by consumer purchasing decisions directly or indirectly. The population in this study are all customers who use EDC Yokke. The sample in this study uses a sample of the slovin formula totaling 100 customers who use Electronic Data Capture. Data collection techniques in this study used documentation, observation, and questionnaire techniques. The data analysis technique in this study uses a quantitative approach using statistical analysis by using the Outer Model Analysis test, Inner Model Analysis, and Hypothesis Testing. Data processing in this study using the PLS (Partial Least Square) software program. The results of this study prove that directly lifestyle, promotion and purchasing decisions have a significant effect on consumer satisfaction, lifestyle and promotions have a significant effect on purchasing decisions, and indirectly purchasing decisions are able to mediate the influence of lifestyle and promotion on consumer satisfaction At EDC Yokke which means purchase decision acts as an intermediary variable..
\end{abstract}

Kata Kunci Lifestyle, Promotion, Consumer Satisfaction and Purchase Decision

\section{PENDAHULUAN}

Perkembangan perbankan saat ini memberikan dan menawarkan kemudahan bagi nasabah melalui layanan operasional yang sangat beragam, termasuk Perkembangan perbankan saat ini memberikan dan menawarkan kemudahan bagi konsumen melalui layanan operasional yang sangat beragam, termasuk layanan E-Banking (electronic banking). Layanan E-Banking saat ini dimiliki oleh hampir semua bank umum yang ada, baik dengan jenis saluran pengiriman delivery channel yang sangat umum (seperti ATM) maupun dengan jenis delivery channel lainnya seperti SMS, telepon, EDC (Electronic Data Capture) dan internet. Hal tersebut juga sejalan dengan kecenderungan perkembangan media sosial maupun kebijakan yang ada untuk mewujudkan atau mengarahkan transaksi masyarakat agar tidak selalu dengan 
uang tunai (less cash society), sehingga masyarakat atau pelaku ekonomi dapat memanfaatkan layanan perbankan modern yang lebih efisien dan efektif melalui E-Banking.

Hal ini dikarenakan antara lain layanan E-Banking memiliki fitur yang menarik dan nyaman digunakan serta memberi kemudahan bagi konsumen untuk melakukan transaksi keuangan seperti transfer antar-bank, pembayaran kartu kredit, pembayaran listrik, pembayaran telepon, pembayaran tagihan ponsel, pembayaran asuransi, pembayaran internet, pembayaran tiket penerbangan, dan virtual account. Selain itu semakin marak bisnis daring (online shop) serta pertumbuhan jenis dan jumlah smartphone yang semakin meningkat telah memberikan andil dalam pertumbuhan transaksi melalui E-Banking.

Pertumbuhan E-Banking yang didukung dengan perkembangan teknologi, media sosial dan pola hidup masyarakat memberikan manfaat bagi industri perbankan antara lain menghasilkan pendapatan dari fee-based income, mengurangi biaya transaksi, pengembangan bisnis, dan meningkatkan kepercayaan atau loyalitas konsumen. Penggunaan E-Banking juga memberikan kenyamanan dan kemudahan bertransaksi secara bebas, tidak terbatas oleh waktu dan lokasi.

Pada saat ini juga banyak perubahan terkait teknologi di perbankan, dari transaksi yang wajib ke teller sekarang dapat dilakukan melalui ATM, EDC dan Mobile Banking. Salah satu produk E-Banking yang sedang berkembang adalah mesin EDC yang sangat membantu dalam kegiatan transaksi non tunai. Mesin EDC merupakan salah satu alat pendukung dan pemicu percepatan budaya baru. EDC merupakan mesin elektronik yang digunakan untuk memproses transaksi non tunai dengan menggunakan kartu pembayaran elektronik. Dengan mesin EDC, transaksi keuangan di tingkat konsumen menjadi lebih mudah dan yang pasti lebih efisien. Saat ini EDC tidak hanya dipakai untuk transaksi kartu kredit, transaksi debit dan transaksi isi ulang (top-up) namun juga untuk transaksi online seperti Shopee, Buka Lapak, Dana, Linkaja dan lainnya. Masing-masing jenis transaksi itu masih bisa dikembangkan lagi, sesuai dengan kebutuhan masyarakat dan ide merchant. Saat ini yang juga berkembang adalah EDC Agen yang dapat berfungsi sebagai alat transfer, setor dan tarik tunai, pembayaran listrik, air dan lain sebagainya.

Dalam rangka meningkatkan pelayanan dan memberikan kemudahan kepada konsumen dalam melakukan transaksi perbankan di Bank, maka perlu mengembangkan sistem informasi teknologi yang mampu menghasilkan tingkat pelayanan yang lebih cepat, terpercaya, dan handal, serta jangkauan pelayanan yang lebih luas tanpa dibatasi dengan kendala wilayah dan waktu. Salah satu sarana yang dibutuhkan adalah dengan menyediakan sarana layanan E-Banking menggunakan EDC Yokke.

Untuk itu beberapa bank menggunakan jasa PT Mitra Transaksi Indonesia dalam hal pengelolaan EDC nya. PT. Mitra Transaksi Indonesia atau yang dikenal juga dengan nama dagang Yokke merupakan anak perusahaan Perseroan dimana kepemilikan sahamnya 100\% oleh Bank Mandiri. PT Mitra Transaksi Indonesia (Yokke) bergerak dalam bidang usaha acquiring Aggregator. PT Mitra Transaksi Indonesia (Yokke) menyediakan sarana layanan E-Banking yang menggunakan EDC Yokke, akan tetapi ada masyarakat (pemegang kartu debit/kredit dan gerai pengguna EDC) yang kurang puas terhadap mesin EDC yang diluncurkan oleh PT Mitra Transaksi Indonesia (Yokke).

\section{LANDASAN TEORI}

\section{Kepuasan Konsumen}

Dalam dunia bisnis yang kerap berhubungan dengan konsumen, maka kepuasan konsumen merupakan prioritas utama yang harus diperhatiakan oleh penyedia jasa.

Menurut (Assauri, 2012) menyatakan bahwa : "Kepuasan pelanggan merupakan pendorong utama bagi retensi dan loyalitas pelanggan. Sebagian pelanggan mendasarkan kepuasannya semata-mata hanya pada dorongan harga, sedangkan kebanyakan pelanggan lainnya mendasarkan kepuasannya kepada keputusan pembelian atas dasar tingkat kepuasan produk 
yang mereka butuhkan". Sedangkan menurut (Kotler \& Keller, 2009) menyatakan bahwa : "Kepuasan merupakan tingkat perasaan dimana seseorang menyatakan hasil perbandingan atas kinerja produk jasa yang diterima dengan yang diharapkan".

Adapun pengertian kepuasan pelanggan menurut (Zeithaml et al., 2012) adalah perbandingan antara persepsi pelanggan terhadap jasa yang diterima dan harapannya sebelum menggunakan jasa tersebut. Dari beberapa pengertian dari para ahli di atas dapat disimpulkan bahwa kepuasan pelanggan adalah sikap emosional yang timbul akibat dari harapan akan sebuah kinerja yang telah dirasakan setelah suatu pemakaian produk/jasa. Untuk jasa atau layanan dengan kualitas yang sama, dapat memberikan tingkat kepuasan yang berbeda-beda bagi konsumen yang berbeda. Oleh karena itu, suatu perusahaan harus selalu memperhatikan kualitas dari jasa yang ditawarkan sehingga tingkat kepuasan dari konsumen dapat lebih tinggi.

\section{Indikator Kepuasan Konsumen}

Kepuasan konsumen merupakan suatu hal yang harus diperhatikan oleh penyedia jasa, kepuasan pelanggan dapat diketahui melalui beberapa indikator. Seperti menurut Menurut (Tjiptono, 2014) ada konsep inti mengenai objek pengukuran, berikut indikator kepuasan Pelanggan:

1. Kepuasan pelanggan keseluruhan (overal customer satisfaction) Pelanggan langsung ditanya seberapa puas dengan produk atau jasa. Kepuasan diukur berdasar produk atau jasa perusahaan bersangkutan dan membandingkan dengan tingkat kepuasan keseluruhan terhadap produk atau jasa pesaing.

2. Dimensi Kepuasan Pelanggan Mengidentifikasi dimensi-dimensi kunci kepuasan pelanggan dan meminta pelanggan menilai produk atau jasa secara spesifik seperti kecepatan layanan, fasilitas layanan dan keramahan staff.

3. Konfirmasi harapan Kepuasan tidak diukur langsung, namun disimpulkan berdasarkan kesesuaian/ketidaksesuaian antara harapan dengan kinerja aktual produk pada beberapa atribut penting.

4. Minat pembelian ulang Kepuasan pelanggan diukur bedasar perilaku dengan jalan menanyakan pelanggan apakah akan berbelanja atau menggunakan jasa perusahaan lagi.

5. Kesediaan untuk merekomendasi Dalam kasus produk yang pembelian ulangnya relatif lama atau bukan hanya terjadi satu kali pembelian (seperti pembelian mobil, asuransi jiwa, tur keliling) kesediaan pelanggan untuk merekomendasikan produk kepada teman atau keluarga.

6. Ketidakpuasan Pelanggan Ketidakpuasan pelanggan meliputi komplen, retur, biaya garansi, productrecall, dan konsumen yang beralih ke pesaing.

\section{Gaya Hidup}

Gaya hidup menggambarkan keseluruhan diri seseorang dalam berinteraksi dengan lingkungannya dan menggambarkan seluruh pola seseorang dalam beraksi dan berinteraksi di masyarakat. Gaya hidup adalah fungsi dari karakteristik individu yang telah terbentuk melalui interaksi sosial. Secara sederhana gaya hidup juga dapat diartikan sebagai cara yang ditempuh seseorang dalam menjalani hidupnya, yang meliputi aktivitas, minat, kesukaan/ketidaksukaan, sikap, konsumsi dan harapan. Gaya hidup merupakan pendorong dasar yang mempengaruhi kebutuhan dan sikap individu, juga memengaruhi aktivitas pembelian dan penggunaan produk. Dengan demikian, gaya hidup merupakan aspek utama yang memengaruhi proses pengambilan keputusan seseorang dalam membeli produk. Menurut (Sunarto, 2015), mendefinisikan gaya hidup atau life style adalah pola kehidupan seseorang untuk memahami kekuatan-kekuatan ini kita harus mengukur dimensi AIO (activities, interest, opinion) utama konsumen aktivitas (pekerjaan, hobi, belanja, olahraga, kegiatan sosial), minat (makanan, mode, keluarga, rekreasi), pendapat (mengenai diri mereka 
sendiri, masalah-masalah sosial, bisnis, produk). Gaya hidup suatu masyarakat akan berbeda dengan masyarakat yang lainnya. Bahkan, dari masa kemasa gaya hidup suatu individu dan kelompok masyarakat tertentu akan bergerak dinamis. Menurut (Wardhani et al., 2015), Gaya hidup kebanyakan dilukiskan dengan kegiatan, minat dan opini dari seseorang (activities, interests, and opinions). Sedangkan (Kotler \& Amstrong, 2012) mendefinisikan bahwa gaya hidup menangkap sesuatu yang lebih dari sekedar kelas sosial atau kepribadian seseorang. Gaya hidup menampilkan profil seluruh pola tindakan dan interaksi seseorang di dunia.

\section{Indikator Gaya Hidup}

Setiap orang mempunyai gaya hidup yang tidak permanen dan cepat berubahubah. Terdapat tiga indikator gaya hidup seseorang yaitu sebagai berikut (Mandey, 2009)

1. Kegiatan (Activity) adalah hal-hal apa yang dikerjakan oleh konsumen, berkaitan dengan produk apa yang dibeli atau yang akan digunakan, kegiatan apa yang dilakukan untuk mengisi waktu luang. Walaupun kegiatan ini biasanya dapat diamati, alasan untuk tindakan tersebut jarang dapat diukur secara langsung.

2. Minat (Interest) Merupakan apa saja yang menarik untuk konsumen berkaitan dengan produk untuk memenuhi kebutuhan dan keinginannya. Interest dapat berupa kesukaan, kegemaran dan prioritas dalam hidup konsumen tersebut.

3. Opini (Opinion) adalah Pandangan maupun perasaan konsumen dalam menanggapi atau mendiskripsikan penapsiran mengenai produk yang bersifat global maupun lokal. Dimanai digunakan untuk mendeskripsikan penafsiran, harapan dan evaluasi, seperti kepercayaan mengenai maksud orang lain, antisipasi sehubungan dengan peristiwa masa datang dan penimbangan konsekuensi yang memberi ganjaran atau menghukum dari jalannya tindakan alternative.

Selanjutnya (Peter \& Oloson, 2012) mengemukakan bahwa gaya hidup diukur dengan bertanya pada konsumen tentang :

1. kegiatan mereka (pekerjaan, hobi, liburan), minat (keluarga, pekerjaan, komunitas), dan

2. Opini (tentang isu sosial, isu politik, bisnis).

\section{Promosi}

Setelah perusahaan menentukan produk yang bermutu, menetapkan harga yang sesuai dengan nilai produk, dan menetapkan produk pada tempatnya yang mudah dijangkau oleh konsumen,aktivitas selanjutnya yang harus diperhatikan oleh perusahaan adalah melakukan promosi.Promosi merupakan salah satu faktor penentu keberhasilan suatu program pemasaran. Menurut (Alma, 2018) promosi itu adalah sejenis komunikasi yang memberi penjelasan yang meyakinkan calon konsumen tentang barang dan jasa. Sedangkan menurut (Lamb et al., 2001) promosi adalah komunikasi dari para pemasar yang menginformasikan, membujuk, dan mengingatkan para calon pembeli suatu produk dalam rangka mempengaruhi pendapat mereka atau memperoleh suatu respons. Selanjutnya menurut (Cannon \& McCharthy, 2008) promosi adalah mengomunikasikan informasi antara penjual dan pembeli potensional atau orang lain dalam saluran untuk memengaruhi sikap dan perilaku.

\section{Indikator promosi}

Selain memperhatikan alat-alat promosi penjualan perusahaan harus bisa memilih indikator-indikator promosi penjualan yang tepat dalam mempromosikan produk.

Menurut (Kotler \& Amstrong, 2012) indikator promosi antara lain:

1. Frekuensi promosi

Jumlah promosi yang dilakukan dalam waktu melalui media promosi.

2. Kualitas promosi 
Tolak ukur seberapa baik promosi dilakukan.

3. Kuantitas promosi

Nilai atau jumlah yang diberikan konsumen terhadap promosi.

4. Waktu promosi

Seberapa lama jangka waktu promosi dilaksanakan atau dilakukan oleh perusahaan.

5. Ketepatan atau kesesuaian promosi

Faktor yang dilakukan untuk mencapai target promosi.

\section{Keputusan Pembelian}

Keinginan membeli konsumen merupakan suatu hal yang tersembunyi dalam hati konsumen yang mana tak ada seorang pun yang bisa tau apa yang diinginkan dan yang diharapkan oleh konsumen. Niat membeli terlihat dari perilaku konsumen dan sikap terhadap suatu produk dan keyakinan tersebut juga akan menyebabkan naik turunnya minat beli konsumen. Menurut (Sangadji \& Sopia, 2013) mendefinisikan "keputusan sebagai pemilihan suatu tindakan dari dua pilihan alternatif atau lebih seorang konsumen yang hendak memilih harus memiliki pilihan alternatif". Suatu keputusan tanpa pilihan disebut "pilihan hobson". Menurut (Setiadi, 2013) mendefinisikan bahwa suatu keputusan (decision) melibatkan pilihan di antara dua atu lebih alternatif tindakan (atau perilaku). Keputusan selalu mensyaratkan pilihan di antara beberapa perilaku yang berbeda. Selanjutnya menurut (Arianty, 2016) "keputusan pembelian adalah tahap dalam proses pengambilan keputusan pembeli dimana konsumen benar-benar membeli". Pengambilan keputusan merupakan suatu kegiatan individu yang secara langsung terlibat dalam mendapatkan, mempergunakan dan mengatur pembeli produk maupun jasa. Jadi dalam penjelasan diatas dapat disimpulkan bahwa keputusan pembelian adalah semua perilaku sengaja dilandaskan pada keinginan yang dihasilkan ketika konsumen secara sadar memilih salah satu diantara tindakan alternatif yang ada.

\section{Indikator Keputusan Pembelian}

Indikator keputusan pembelian merupakan tindakan yang dilakukan oleh konsumen dalam upaya memecahkan masalah dalam upaya pemenuhan kebutuhan. Sebelum memutuskan untuk melakukan pembelian konsumen sering kali di hadapkan pada alternatif yang beragam. Menurut (Rahmadika \& Kristaningsih, 2018) adalah sebagai berikut:

1. Prioritas pembelian, dimana seseorang memprioritaskan yang menjadi kebutuhan dari dirinya sendiri.

2. Kemudahan mendapat/ memperoleh, dimana konsumen mendapatkan informasi yang detail untuk memperoleh produk yang di inginkan.

3. Pertimbangkan manfaat, konsumen lebih mengutamakan kualitas dari produk yang ingin dibeli.

4. Keyakinan dalam membeli, timbul keyakinan pada diri individu terhadap produk tersebut sehingga menimbulkan keputusan (proses akhir) untuk memperolehnya dengan tindakan yang di sebut membeli.

Proses pembelian berlangsung jauh sebelum pembelian aktual dan berlanjut jauh sesudahnya. Untuk itu pemasar perlu berfokus pada seluruh proses pengambilan keputusan bukan hanya pada proses pembeliannya saja.

Menurut (Kotler \& Keller, 2012) menyatakan adapun indikator dari pengambilan keputusan pembelian, diantaranya sebagai berikut :

1. Pembelian produk, suatu pembelian yang dilakukan konsumen dalam membeli barang yang di inginkan.

2. Pembelian merk, suatu pembelian yang dilakukan konsumen hanya berupa merk tidak berupa barang. 
3. Pemilihan saluran pembelian, setiap barang yang ingin dibeli konsumen harus dipilih terlebih dahulu dalam saluran pembelian.

4. Penentuan waktu pembelian, setiap konsumen ingin membeli barang atau produk yang diinginkan konsumen harus terlebih dahulu memutuskan kapan waktu pembelian yang sudah di jadwalkan.

5. Jumlah, berapa banyak produk yang di inginkan konsumen.

\section{Hubungan Gaya Hidup Terhadap Kepuasan Konsumen}

Gaya hidup menggambarkan keseluruhan diri seseorang dalam berinteraksi dengan lingkungannya dan menggambarkan seluruh pola seseorang dalam beraksi dan berinteraksi di masyarakat. Gaya hidup adalah fungsi dari karakteristik individu yang telah terbentuk melalui interaksi social (Rahmadika \& Kristaningsih, 2018). Gaya hidup seseorang mempengaruhi kepuasan pembelian, yang bisa menentukan banyak tingkat kepuasan perorangan. gaya hidup menunjukkan bagaimana seseorang mengalokasikan pendapatannya, dan memilih produk maupun jasa dan berbagai pilihan lainnya ketika memilih alternatif dalam satu kategori jenis produk yang ada sampai akhirnya konsumen tersebut merasa puas terhadap apa yang diperolehnya (Muchsin, 2017).

Hipotesis : Gaya hidup berpengaruh signifikan terhadap kepuasan konsumen.

\section{Hubungan Promosi Terhadap Kepuasan Konsumen}

Promosi merupakan salah satu kegiatan pemasaran yang penting bagi perusahaan dalam upaya mempertahankan kontiniutas serta meningkatkan kualitas penjualan. Untuk menigkatkan kegiatan pemasaran dalam hal memasarkan barang atau jasa dari suatu perusahaan, tak cukup hanya mengembangkan model unit perumahan, penggunakan saluran distribusi dan saluran harga yang tetap, tetapi juga didukung oleh kegiatan promosi (Listiawati, 2017). Promosi yang diberikan perusahaan dan kepuasan konsumen berhubungan erat dengan keuntungan yang akan di dapat oleh perusahaan, karena dengan promosi yang memenuhi preferensi konsumen akan mengikat konsumen sehingga perusahaan tersebut tertanam dalam benak konsumen, hal ini tentunya menguntungkan bagi pihak perusahaan karena konsumen dapat melakukan promosi secara tidak langsung kepada teman, keluarga ataupun kepada orang lain untuk mengkonsumsi produk atau jasa dari prusahaan tersebut. (Aryani \& Rosinta, 2010).

Hipotesis : Promosi berpengaruh signifikan terhadap kepuasan konsumen.

\section{Hubungan Keputusan Pembelian Terhadap Kepuasan Konsumen}

Keinginan membeli konsumen merupakan suatu hal yang tersembunyi dalam hati konsumen yang mana tak ada seorang pun yang bisa tau apa yang diinginkan dan yang diharapkan oleh konsumen. Niat membeli terlihat dari perilaku konsumen dan sikap terhadap suatu produk dan keyakinan tersebut juga akan menyebabkan naik turunnya minat beli konsumen. Keputusan sebagai pemilihan suatu tindakan dari dua pilihan alternatif atau lebih seorang konsumen yang hendak memilih harus memiliki pilihan alternatif'. Suatu keputusan tanpa pilihan disebut "pilihan hobson" (Sangadji \& Sopia, 2013). Apabila perusahaan dapat memberikan atau menawarkan produk yang berkualitas maka konsumen akan cenderung akan membeli produk tersebut, sehingga perusahaan akan dapat menciptakan kepuasan konsumen. Seorang pelanggan akan merasa puas biasanya dikarenakan adanya pengalaman melakukan pembelian terhadap suatu produk yang dikonsumsi atau digunakan. Kepuasan pelanggan merupakan ungkapan perasaan seorang pelanggan yang digambarkan setelah membandingkan apa yang diharapkan dengan apa yang ditawarkan perusahaan (Angreani, 2016).

Hipotesis : Keputusan Pembelian berpengaruh signifikan terhadap kepuasan konsumen

\section{Hubungan Gaya Hidup Terhadap Keputusan Pembelian}


Gaya hidup atau life style adalah pola kehidupan seseorang untuk memahami kekuatan-kekuatan ini harus mengukur dimensi AIO (activities, interest, opinion) utama konsumen aktivitas (pekerjaan, hobi, belanja, olahraga, kegiatan sosial), minat (makanan, mode, keluarga, rekreasi), pendapat (mengenai diri mereka sendiri, masalah-masalah sosial, bisnis, produk) (Sunarto, 2013). Gaya hidup suatu masyarakat akan berbeda dengan masyarakat yang lainnya. Bahkan, dari masa ke masa gaya hidup suatu individu dan kelompok masyarakat tertentu akan bergerak dinamis. Gaya hidup tidak cepat berubah sehingga pada kurun waktu tertentu gaya hidup relatif permanen (Setiadi, 2013)

Hipotesis : Gaya hidup berpengaruh signifikan terhadap keputusan pembelian.

\section{Hubungan Promosi Terhadap Keputusan Pembelian}

Promosi adalah arus informasi atau persuasi searah yang dibuat untuk mengarahkan seseorang atau organisasi kepada tindakan yang menciptakan pertukaran dalam pemasaran (Susilo et al, 2018). Promosi dipandang sebagai kegiatan komunikasi pembeli dan penjual dan merupakan kegiatan yang membantu dalam pengambilan keputusan di bidang pemasaran serta mengarahkan dan menyadarkan semua pihak untuk berbuat lebih baik (Swastha, 2010) Menurut (Rangkuti, 2009) yang menyatakan bahwa promosi dapat mendorong konsumen dalam melakukan pemilihan terhadap suatu produk dan memberi dukungan atau memfasilitasi konsomen dalam proses melakukan pembelian.

Hipotesis : promosi berpengaruh signifikan terhadap keputusan pembelian

\section{Hubungan Gaya Hidup Terhadap Keputusan Pembelian Melalui Kepuasan Konsumen}

Gaya hidup merupakan pendorong dasar yang mempengaruhi kebutuhan dan sikap individu, juga memengaruhi aktivitas pembelian dan penggunaan produk. Dengan demikian, gaya hidup merupakan aspek utama yang memengaruhi proses pengambilan keputusan seseorang dalam membeli produk melalui. Gaya hidup seseorang mempengaruhi kepuasan pembelian, yang bisa menentukan banyak tingkat kepuasan perorangan. gaya hidup menunjukkan bagaimana seseorang mengalokasikan pendapatannya, dan memilih produk maupun jasa dan berbagai pilihan lainnya ketika memilih alternatif dalam satu kategori jenis produk yang ada sampai akhirnya konsumen tersebut merasa puas terhadap apa yang diperolehnya sehingga loyalitas konsumen untuk membeli produk tersebut akan semkin meningkat.

\section{Hubungan Promosi Terhadap Kepuasan Konsumen Melalui Keputusan Pembelian}

Promosi merupakan salah satu faktor penentu keberhasilan suatu program pemasaran. Pada hakekatnya promosi adalah suatu bentuk komunikasi pemasaran. Komunikasi pemasaran adalah aktivitas pemasaran yang berusaha menyebarkan informasi mempegaruhi atau membujuk, menginatkan pasar sasaran atas perusahaan dan produksinya agar bersedia menerima, membeli dan loyal pada produk yang ditawarkan(Tjiptono, 2014).

Promosi yang diberikan perusahaan dan kepuasan konsumen berhubungan erat dengan keuntungan yang akan di dapat oleh perusahaan, karena dengan promosi yang memenuhi preferensi konsumen akan mengikat konsumen dimana promosi yang dilakukan oleh perusahaan dapat meningkatkan penjualan perusahaan dan produk yang diterima sesuai dengan promosi yang di lakukan oleh perusahaan maka konsumen tersebut akan merasa kepuasan.

\section{METODOLOGI PENELITIAN}

Jenis penelitian ini adalah penelitian survey, penelitian kausal, penelitian kuantitatif. Data yang digunakan dalam penelitian ini adalah data primer yaitu data yang diperoleh dan harus diolah kembali, yaitu kuesioner. Dalam melakukan pengumpulan data yang berhubungan dengan yang akan dibahas dilakukan langsung dilakukan dengan dengan cara 
metode kuesioner. Metode kuesioner adalah teknik pengumpulan data melalui formulir berisi pertanyaan-pertanyaan yang diajukan secara tertulis pada seseorang atau sekumpulan orang untuk mendapatkan jawaban atau tanggapan serta informasi yang diperlukan. Populasi dalam penelitian ini adalah seluruh nasabah Bank Mandiri yang menggunakan Elektronik Data Capture yang berjumlah 680.713 orang. Berdasarkan perhitungan slovin diatas maka, jumlah sampel dalam penelitian ini adalah sebanyak 100 orang nasabah Bank Mandiri yang menggunakan Elektronik Data Capture. Pengambilan sampel ini menggunakan metode Nonprobability Sampling dengan menggunakan teknik Insidental sampling. Teknik analisis data dalam penelitian ini menggunakan pendekatan kuantitatif menggunakan analisis statistik dengan menggunakan uji Analisis Auter Model, Analisis Inner Model, dan Uji Hipotesis. Pengolahan data dalam penelitian ini menggunakan program software PLS (Partial Least Square).

\section{HASIL DAN PEMBAHASAN \\ Analisis Inner Model}

$R$-Square adalah ukuran proporsi variasi nilai yang dipengaruhi (endogen) yang dapat dijelaskan oleh variabel yang mempengaruhinya (eksogen) ini berguna untuk memprediksi apakah model adalah baik/buruk. Hasil $R$-Square untuk variabel laten endogen sebesar 0,75 mengindikasikan bahwa model tersebut adalah substansial (baik); 0,50 mengindikasikan bahwa model tersebut adalah moderat (sedang) dan 0,25 mengindikasikan bahwa model tersebut adalah lemah (buruk) (Juliandi, 2018). Berdasarkan pengolahan data yang telah dilakukan dengan menggunakan program smartPLS 3. 0, diperoleh nilai $R$-Square yang dapat dilihat pada gambar dan tabel berikut:

Tabel 1. Hasil Uji R-Square

\begin{tabular}{|l|llll|}
\hline & R Square & R Square Adjusted & \\
\hline $\mathbf{Y}$ & & 0.951 & & 0.949 \\
\hline
\end{tabular}

\section{Sumber : PLS 3.00}

Dari tabel 5 di atas diketahui bahwa pengaruh X1, X2 dan Z terhadap Y dengan nilai r-square 0,951 mengindikasikan bahwa variasi nilai $Y$ mampu dijelaskan oleh variasi nilai $X 1, X 2$ dan $\mathrm{Z}$ sebesar $95,1 \%$ atau dengan kata lain bahwa model tersebut adalah substansial (baik), dan $4,9 \%$ dipengaruhi oleh variabel lain.

\section{PENGUJIAN HIPOTESIS}

Pengujian ini adalah untuk menentukan koefisien jalur dari model struktural. Tujuannya adalah menguji signifikansi semua hubungan atau pengujian hipotesis. Pengujian hipotesis dalam penelitian ini dibagi menjadi pengaruh langsung dan pengaruh tidak langsung. Berdasarkan pengolahan data yang telah dilakukan menggunakan program smart PLS 3.0, gambar hasil uji hipotesis pengaruh langsung dan tidak langsung dapat dilihat pada gambar path coefficient berikut ini : 


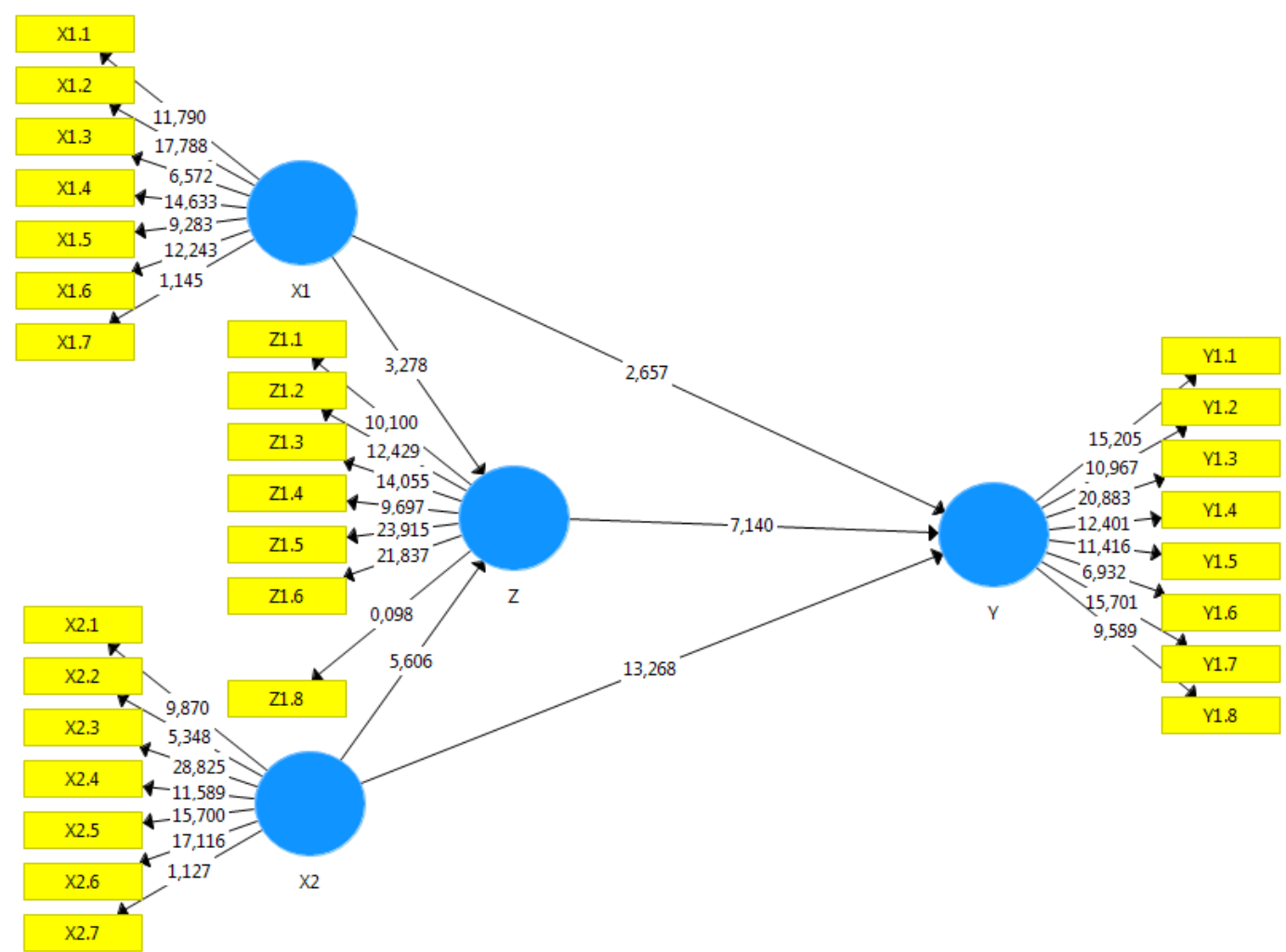

\section{Gambar 1. Path Coefficient}

\section{Pengujian Hipotesis Langsung} ini:

Hasil uji hipotesis pengaruh langsung dapat dilihat pada tabel path coefficient berikut

Tabel 2. Path Coefficient

\begin{tabular}{|c|c|c|c|c|c|}
\hline & $\begin{array}{l}\text { Original } \\
\text { Sample (O) }\end{array}$ & $\begin{array}{l}\text { Sample } \\
\text { Mean (M) }\end{array}$ & $\begin{array}{l}\text { Standard Error } \\
\text { (STERR) }\end{array}$ & $\begin{array}{l}\text { T Statistics } \\
\text { (|O/STERR })\end{array}$ & $\begin{array}{l}\mathbf{P} \\
\text { Values }\end{array}$ \\
\hline X1 -> Y & $-0,139$ & $-0,132$ & 0,052 & 2,657 & 0.008 \\
\hline $\mathrm{X} 1$-> Z & 0,358 & 0,354 & 0,109 & 3,278 & 0.001 \\
\hline X2 -> Y & 0,779 & 0,781 & 0,059 & 13,268 & 0.000 \\
\hline $\mathrm{X} 2$-> Z & 0,511 & 0,518 & 0,091 & 5,606 & 0.000 \\
\hline Z -> Y & 0,360 & 0,350 & 0,050 & 7,140 & 0.000 \\
\hline
\end{tabular}

\section{Sumber : PLS 3.00} berikut:

Berdasarkan Tabel 2 di atas, dapat dinyatakan bahwa pengujian hipotesis adalah sebagai

1. Pengaruh gaya hidup terhadap kepuasan konsumen mempunyai koefisien jalur sebesar 0,139 . Pengaruh tersebut mempunyai nilai probabilitas ( $\mathrm{p}$-values) sebesar $0,008<0,05$, berarti gaya hidup berpengaruh signifikan terhadap kepuasan konsumen Di EDC (Elektronik Data Capture) Yokke.

2. Pengaruh gaya hidup terhadap keputusan pembelian mempunyai koefisien jalur sebesar 0,779 . Pengaruh tersebut mempunyai nilai probabilitas ( $\mathrm{p}$-values) sebesar $0,000<0,05$, berarti gaya hidup berpengaruh signifikan terhadap keputusan pembelian Di EDC (Elektronik Data Capture) Yokke.

3. Pengaruh promosi terhadap kepuasan konsumen mempunyai koefisien jalur sebesar 0,139 . Pengaruh tersebut mempunyai nilai probabilitas ( $\mathrm{p}$-values) sebesar $0,008<0,05$, 
berarti promosi berpengaruh signifikan terhadap kepuasan konsumen Di EDC (Elektronik Data Capture) Yokke.

4. Pengaruh promosi terhadap keputusan pembelian mempunyai koefisien jalur sebesar 0,511. Pengaruh tersebut mempunyai nilai probabilitas ( $\mathrm{p}$-values) sebesar $0,000<0,05$, berarti promosi berpengaruh signifikan terhadap keputusan pembelian Di EDC (Elektronik Data Capture) Yokke.

5. Pengaruh keputusan pembelian terhadap kepuasan konsumen mempunyai koefisien jalur sebesar 0,360 . Pengaruh tersebut mempunyai nilai probabilitas (p-values) sebesar 0,000 $<0,05$, berarti keputusan pembelian berpengaruh signifikan terhadap kepuasan konsumen Di EDC (Elektronik Data Capture) Yokke.

\section{Pengujian Hipotesis Tidak Langsung}

Adapun pengaruh tidak langsung diantara variabel bebas dan variabel terikat pada penelitian ini dapat dikemukakan adalah sebagai berikut :

\begin{tabular}{|l|l|l|l|l|l|}
\hline \multicolumn{1}{|c|}{ Tabel 3. Specific Indirect Effects } \\
\hline & $\begin{array}{l}\text { Original } \\
\text { Sample } \\
(\mathbf{O})\end{array}$ & $\begin{array}{l}\text { Sample } \\
\text { Mean } \\
(\mathbf{M})\end{array}$ & $\begin{array}{l}\text { Standard } \\
\text { Deviation } \\
\text { (STDEV) }\end{array}$ & $\begin{array}{l}\text { T Statistics } \\
(\mid \text { O/STDEV|) }\end{array}$ & $\begin{array}{l}\text { P } \\
\text { Values }\end{array}$ \\
\hline X1 $>$ - Z $>$ Y Y & 0.129 & 0.123 & 0.040 & 3,240 & $\mathbf{0 . 0 0 1}$ \\
\hline X2 $>>$ Z $>$ Y Y & 0.184 & 0.181 & 0.043 & 4,265 & $\mathbf{0 . 0 0 0}$ \\
\hline
\end{tabular}

\section{Sumber : PLS 3.00}

Berdasarkan Tabel 3 di atas, dapat dinyatakan bahwa pengujian hipotesis adalah sebagai berikut:

1. Pengaruh gaya hidup terhadap kepuasan konsumen melalui keputusan pembelian mempunyai koefisien jalur sebesar 0,129 . Pengaruh tersebut mempunyai nilai probabilitas (p-values) sebesar $0,001<0,05$, berarti dapat disimpulkan bahwa gaya hidup berpengaruh signifikan terhadap kepuasan konsumen Di EDC (Elektronik Data Capture) Yokke melalui Keputusan Pembelian Konsumen.

2. Pengaruh promosi terhadap kepuasan konsumen melalui keputusan pembelian mempunyai koefisien jalur sebesar 0,184 . Pengaruh tersebut mempunyai nilai probabilitas (p-values) sebesar $0,000<0,05$, berarti dapat disimpulkan bahwa promosi berpengaruh signifikan terhadap kepuasan konsumen Di EDC (Elektronik Data Capture) Yokke melalui Keputusan Pembelian Konsumen.

\section{PEMBAHASAN}

\section{Pengaruh Gaya Hidup Terhadap Kepuasan Konsumen}

Dari hasil analisis pengujian hipotesis diketahui bahwa gaya hidup berpengaruh signifikan terhadap kepuasan konsumen yang dinilai dengan koefisien jalur sebesar -0,139. Nilai probabilitas yang didapatkan adalah sebesar $0,008<0,05$, dengan nilai thitung sebesar 2,657 , dan nilai $t_{\text {tabel }} 1.96$, dengan demikian $t_{\text {hitung }}$ lebih besar dari $t_{\text {tabel }}(2,657>1.96)$ sehingga $\mathrm{H} 0$ ditolak (Ha diterima). Hal ini berarti gaya hidup berpengaruh signifikan terhadap kepuasan konsumen di EDC Yokke. Dengan meningkatnya gaya hidup konsumen maka kepuasan konsumen EDC Yokke akan semakin meningkat dimana dengan gaya hidup konsumen yang selalu mengikuti perkembangan zaman sehingga minat individu akan sesuatu yang baru, unik dan praktis serta sifat individu itu sendiri senantiasa mengikuti tren, dengan menggunakan EDC Yokke keinginan konsumen akan terpenuhi sehingga demikian konsumen akan merasa puas atas apa yang akan diterimanya

Dengan demikian maka gaya hidup berpengaruh signifikan terhadap kepuasan konsumen di EDC Yokke. Hal ini menunjukkan bahwa dengan meningkatnya gaya hidup konsumen maka 
kepuasan konsumen EDC Yokke akan semakin meningkat dimana dengan gaya hidup konsumen yang selalu mengikuti perkembangan zaman sehingga minat individu akan sesuatu yang baru.

Gaya hidup menggambarkan keseluruhan diri seseorang dalam berinteraksi dengan lingkungannya dan menggambarkan seluruh pola seseorang dalam beraksi dan berinteraksi di masyarakat. Gaya hidup adalah fungsi dari karakteristik individu yang telah terbentuk melalui interaksi sosial. Gaya hidup seseorang mempengaruhi kepuasan pembelian, yang bisa menentukan banyak tingkat kepuasan perorangan. gaya hidup menunjukkan bagaimana seseorang mengalokasikan pendapatannya, dan memilih produk maupun jasa dan berbagai pilihan lainnya ketika memilih alternatif dalam satu kategori jenis produk yang ada sampai akhirnya konsumen tersebut merasa puas terhadap apa yang diperolehnya. Hasil penelitian ini sejalan dengan hasil penelitian terdahulu yang dilakukan oleh (Muchsin, 2017) menyimpulkan bahwa gaya hidup berpengaruh signifikan terhadap kepuasan konsumen

\section{Pengaruh Promosi Terhadap Kepuasan Konsumen}

Dari hasil analisis pengujian hipotesis diketahui bahwa promosi berpengaruh signifikan terhadap kepuasan konsumen yang dinilai dengan koefisien jalur sebesar 0,779. Nilai probabilitas yang didapatkan adalah sebesar $0,000<0,05$, dengan nilai thitung sebesar 13,268 , dan nilai $t_{\text {tabel }} 1.96$, dengan demikian $t_{\text {hitung }}$ lebih besar dari $t_{\text {tabel }}(13,268>1.96)$ sehingga $\mathrm{H0}$ ditolak (Ha diterima). Hal ini berarti promosi berpengaruh signifikan terhadap kepuasan konsumen di EDC Yokke.

Promosi menurut Tjiptono dalam Selang (2013:73) adalah suatu bentuk komunikasi pemasaran yang merupakan aktivitas pemasaran yang berusaha menyebarkan informasi, mempengaruhi/membujuk, dan/atau meningkatkan pasar sasaran atas perusahaan dan produknya agar bersedia menerima, membeli, dan loyal pada produk yang ditawarkan perusahaan yang bersangkutan. Promosi yang diberikan perusahaan dan kepuasan konsumen berhubungan erat dengan keuntungan yang akan di dapat oleh perusahaan, karena dengan promosi yang memenuhi preferensi konsumen akan mengikat konsumen sehingga perusahaan tersebut tertanam dalam benak konsumen, hal ini tentunya menguntungkan bagi pihak perusahaan karena konsumen dapat melakukan promosi secara tidak langsung kepada teman, keluarga ataupun kepada orang lain untuk mengkonsumsi produk atau jasa dari prusahaan tersebut. (Aryani, D dan Rosinta, F. 2010). Hasil penelitian ini sejalan dengan hasil penelitian terdahulu yang dilakukan oleh Listiawati, Raden Ina Afriani, \& Tuti Solehan, 2017 menyimpulkan bahwa terdapat pengaruh promosi dan harga terhadap kepuasan konsumen. 


\section{Pengaruh Keputusan Pembelian Terhadap Kepuasan Konsumen}

Dari hasil analisis pengujian hipotesis diketahui bahwa keputusan pembelian berpengaruh signifikan terhadap kepuasan konsumen yang dinilai dengan koefisien jalur sebesar 0,360 . Nilai probabilitas yang didapatkan adalah sebesar $0,000<0,05$, dengan nilai

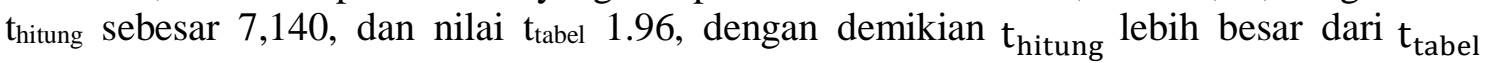
(7,140>1.96) sehingga $\mathrm{H} 0$ ditolak (Ha diterima). Hal ini berarti keputusan pembelian berpengaruh signifikan terhadap kepuasan konsumen di EDC Yokke.

Keputusan sebagai pemilihan suatu tindakan dari dua pilihan alternatif atau lebih seorang konsumen yang hendak memilih harus memiliki pilihan alternatif'. Suatu keputusan tanpa pilihan disebut "pilihan hobson" (Sangadji \& Sopia, 2013).

Dalam jurnal penelitian terdahulu yang dilakukan oleh Angga P. Kautsar, Sunu Widianto, Rizky Abdulah Ph.D, Hesti Amalia (2012), menyatakan bahwa keputusan pembelian mempunyai pengaruh positif terhadap kepuasan konsumen, dengan uji-t sebesar 7,84.

\section{Pengaruh Gaya Hidup Terhadap Keputusan Pembelian}

Dari hasil analisis pengujian hipotesis diketahui bahwa gaya hidup berpengaruh signifikan terhadap keputusan pembelian yang dinilai dengan koefisien jalur sebesar 0,358. Nilai probabilitas yang didapatkan adalah sebesar $0,001<0,05$, dengan nilai thitung sebesar 3,278 , dan nilai tabel 1.96 , dengan demikian $t_{\text {hitung }}$ lebih besar dari $t_{\text {tabel }}(3,278>1.96)$ sehingga $\mathrm{H} 0$ ditolak (Ha diterima). Hal ini berarti gaya hidup berpengaruh signifikan terhadap keputusan pembelian di EDC Yokke. Semakin tinggi gaya hidup seseorang akan mendorong semakin tingginya keputusan pembelian EDC Yokke dimana gaya hidup dapat timbul dari minat individu akan sesuatu yang baru dan unik dan sifat individu itu sendiri senantiasa mengikuti tren. Dengan begitu maka minat individu untuk bertransaksi di EDC Yokke akan semakin tinggi untuk memenuhi keinginan individu tersebut.

Promosi adalah arus informasi atau persuasi searah yang dibuat untuk mengarahkan seseorang atau organisasi kepada tindakan yang menciptakan pertukaran dalam pemasaran (Susilo, Haryono, \& Mukery, 2018). Promosi dipandang sebagai kegiatan komunikasi pembeli dan penjual dan merupakan kegiatan yang membantu dalam pengambilan keputusan di bidang pemasaran serta mengarahkan dan menyadarkan semua pihak untuk berbuat lebih baik (Swastha, 2010). Hasil penelitian ini sejalan dengan hasil penelitian terdahulu yang dilakukan oleh (Lina Purnama, Tri Suyani, \& Hardipamungkas, 2020) dan (Dea Putri Njoto \& Krismi Budi Sienatra, 2018) menyimpulkan bahwa promosi berpengaruh signifikan terhadap keputusan pembelian.

\section{Pengaruh Gaya Hidup Terhadap Kepuasan Konsumen yang di Mediasi oleh Keputusan Pembelian}

Dari hasil analisis pengujian hipotesis diketahui bahwa gaya hidup berpengaruh signifikan terhadap kepuasan konsumen yang dimediasi oleh keputusan pembelian yang dinilai dengan koefisien jalur sebesar 0,129 . Nilai probabilitas yang didapatkan adalah sebesar $0,001<0,05$, dengan nilai thitung sebesar 3,240, dan nilai tabel 1.96, dengan demikian $t_{\text {hitung }}$ lebih besar dari $t_{\text {tabel }}(3,240>1.96)$ sehingga $\mathrm{H} 0$ ditolak (Ha diterima). Hal ini berarti gaya hidup berpengaruh signifikan terhadap kepuasan konsumen yang dimediasi oleh keputusan pembelian Di EDC Yokke.

Gaya hidup seseorang mempengaruhi kepuasan pembelian, yang bisa menentukan banyak tingkat kepuasan perorangan. gaya hidup menunjukkan bagaimana seseorang mengalokasikan pendapatannya, dan memilih produk maupun jasa dan berbagai pilihan lainnya ketika memilih alternatif dalam satu kategori jenis produk yang ada sampai akhirnya 
konsumen tersebut merasa puas terhadap apa yang diperolehnya sehingga loyalitas konsumen untuk membeli produk tersebut akan semakin meningkat.

Dengan demikian maka gaya hidup berpengaruh signifikan terhadap kepuasan konsumen melalui keputusan pembelian Di EDC Yokke. Hal ini menunjukkan bahwa dengan terpenuhinya gaya hidup masyarakat maka keputusan penggunaan akan EDC Yokke akan semakin meningkat dan konsumen akan semakin puas.

\section{Pengaruh Promosi Terhadap Kepuasan Konsumen yang Dimediasi oleh Keputusan Pembelian}

Dari hasil analisis pengujian hipotesis diketahui bahwa promosi berpengaruh signifikan terhadap kepuasan konsumen yang dimediasi oleh keputusan pembelian yang dinilai dengan koefisien jalur sebesar 0,184 . Nilai probabilitas yang didapatkan adalah sebesar $0,000<0,05$, dengan nilai thitung sebesar 4,265, dan nilai tabel 1.96, dengan demikian $t_{\text {hitung }}$ lebih besar dari $t_{\text {tabel }}(4,2654>1.96)$ sehingga $H 0$ ditolak (Ha diterima). Hal ini berarti promosi berpengaruh signifikan terhadap kepuasan konsumen yang dimediasi oleh keputusan pembelian di EDC Yokke.

Promosi merupakan salah satu faktor penentu keberhasilan suatu program pemasaran. Pada hakekatnya promosi adalah suatu bentuk komunikasi pemasaran. Komunikasi pemasaran adalah aktivitas pemasaran yang berusaha menyebarkan informasi mempegaruhi atau membujuk, menginatkan pasar sasaran atas perusahaan dan produksinya agar bersedia menerima, membeli dan loyal pada produk yang ditawarkan(Tjiptono, 2014). Promosi yang diberikan perusahaan dan kepuasan konsumen berhubungan erat dengan keuntungan yang akan di dapat oleh perusahaan, karena dengan promosi yang memenuhi preferensi konsumen akan mengikat konsumen dimana promosi yang dilakukan oleh perusahaan dapat meningkatkan penjualan perusahaan dan produk yang diterima sesuai dengan promosi yang di lakukan oleh perusahaan maka konsumen tersebut akan merasa kepuasan.

\section{KESIMPULAN}

kesimpulan dari penelitian mengenai Pengaruh Gaya Hidup dan Promosi Terhadap Kepuasan Konsumen Di EDC (Electronic Data Capture) Yokke Yang Dimediasi Oleh Keputusan Pembelian Konsumen". (Studi Kasus Pengguna EDC Yokke Bank Mandiri) adalah sebagai berikut.

1. Gaya hidup berpengaruh signifikan terhadap kepuasan konsumen Di EDC (Elektronik Data Capture) Yokke. Hal ini menunjukkan bahwa dengan meningkatnya gaya hidup konsumen maka kepuasan konsumen EDC (Elektronik Data Capture) Yokke akan semakin meningkat dimana dengan gaya hidup konsumen yang selalu mengikuti perkembangan zaman sehingga minat individu akan sesuatu yang baru.

2. Promosi berpengaruh signifikan terhadap kepuasan konsumen Di EDC (Elektronik Data Capture) Yokke. Hal ini menunjukkan bahwa dengan meningkatnya promosi maka kepuasan konsumen EDC (Elektronik Data Capture) Yokke akan semakin meningkat.

3. Keputusan pembelian berpengaruh signifikan terhadap kepuasan konsumen Di EDC (Elektronik Data Capture) Yokke. Hal ini menunjukkan bahwa dengan keputusan pembelian yang dilakukan oleh konsumen terhadap EDC (Elektronik Data Capture) Yokke dimana konsumen merasa sesuai dengan keinginan konsumen maka konsumen tersebut akan merasa puas atas apa yang telah di terimanya.

4. Gaya hidup berpengaruh signifikan terhadap Keputusan Pembelian Konsumen Di EDC (Elektronik Data Capture) Yokke. Hal ini menunjukkan bahwa semakin tinggi gaya hidup seseorang akan mendorong semakin tingginya keputusan pembelian EDC (Elektronik Data Capture) Yokke 
5. Promosi berpengaruh signifikan terhadap Keputusan Pembelian Konsumen Di EDC (Elektronik Data Capture) Yokke. Hal ini menunjukkan bahwa promosi dapat mendorong konsumen dalam melakukan pemilihan terhadap suatu produk dan memberi dukungan atau memfasilitasi konsomen dalam proses melakukan pembelian.

6. Gaya hidup berpengaruh signifikan terhadap kepuasan konsumen Di EDC (Elektronik Data Capture) Yokke melalui Keputusan Pembelian Konsumen. Hal ini menunjukkan bahwa dengan terpenuhinya gaya hidup masyarakat maka keputusan penggunaan akan kartu EDC akan semakin meningkat dan konsumen akan semakin puas.

7. Promosi berpengaruh signifikan terhadap kepuasan konsumen Di EDC (Elektronik Data Capture) Yokke melalui Keputusan Pembelian Konsumen. Hal ini menunjukkan bahwa dengan meningkatnya promosi maka keputusan pembelian akan semakin meningkat serta akan berdampak pada kepuasan konsumen yang semakin meningkat.

\section{DAFTAR PUSTAKA}

Alma, B. (2018). Manajemen Pemasaran \& Pemasaran Jasa. Alfabeta.

Arianty, N. (2016). Manajemen Pemasaran. Perdana Publishing.

Assauri, S. (2012). Manajemen Pemasaran. PT. Raja Grafindo Persada.

Cannon, P., \& McCharthy. (2008). Manajemen Pemasaran. Salemba Empat.

Kotler, \& Keller. (2009). Manajemen Pemasaran. Erlangga.

Kotler, P., \& Amstrong. (2012). Marketing Management. Erlangga.

Kotler, P., \& Keller, K. L. (2012). Marketing Management. Pearson Education Inc.

Lamb, C. w, Hair, J. F., \& McDaniel, C. (2001). Pemasaran. Salemba Empat.

Listiawati, L., Afriani, R. I., \& Solehan, T. (2017). Pengaruh Promosi dan Harga Terhadap Kepuasan Konsumen Di PT Indomaret Suralaya, Merak Banten. Jurnal Riset Akuntansi Terpadu, 10(2), 31-49.

Mandey, S. L. (2009). Pengaruh Faktor Gaya Hidup Terhadap Keputusan Pembelian Konsumen. Jurnal, 6(1).

Muchsin, M. (2017). Pengaruh Gaya Hidup terhadap Kepuasan Konsumen Blackberry di Kecamatan Dewantara Kabupaten Aceh Utara. Jurnal Visioner \& Strategi, 6(1), 8589.

Njoto, D. P., \& Sienatra, K. B. (2018). Pengaruh Promosi Terhadap Keputusan Pembelian Konsumen Wenak Tok. Jurnal Performa: Jurnal Manajemen Dan Start-Up Bisnis, 3(5), 75-90.

Peter, \& Oloson. (2012). Perilaku Konsumen dan Strategi Pemasaran. Erlangga.

Purnama, L., Suyani, T., \& Hardipamungkas, N. E. (2020). Pengaruh Citra Merek, Harga dan Promosi Terhadap Keputusan Pembelian Jasa Online Gojek Di Kota Tangerang. Jurnal Ilmiah Manajemen Ubhara, 2(1), 1-15.

Rahmadika, N. A., \& Kristaningsih, T. (2018). Pengaruh Brand Imange dan Gaya Hidup Terhadap Keputusan Pembelian Jeans Levi's (Studi Pada Masiswa Aktif DIV Manajemen Pemasaran Jurusan Administrasi Niaga Poleteknik Negeri Malang Tahun 2017/2018). Jurnal Aplikasi Bisnis, 4(2), 301-305.

Rangkuti, F. (2009). Strategi Promosi Yang Kreatif \& Analisis Intergrated. PT. Gramedia Pustaka Utama.

Sangadji, E. M., \& Sopia. (2013). Perilaku Konsumen Pendekatan Praktisi Disertai Himpunan Jurnal Penelitian. CV Andi Offset.

Setiadi, N. J. (2013). Perilaku Konsumen. Kencana Prenada Media Group.

Sunarto, S. (2013). Manajemen Pemasaran. BPFE-UST.

Sunarto, S. (2015). Pengaruh Kualitas Produk Terhadap Keputusan Pembelian Pada Toko Kerajinan Kulit Kartika Magetan. Equilirium: Jurnal Ilmiah Ekonomi Dan Pembelajarannya, 3(2), 1-14.

Swastha, B. (2010). Manajemen Pemasaran. BPFE UGM. 
Tjiptono. (2014). Pemasaran Jasa. Andi.

Wardhani, W., Sumarwan, U., \& Yuliati, L. N. (2015). Pengaruh Persepsi dan Preferensi Konsumen Tehadap Keputusan Pembelian Hunian Green Product. Jurnal Manajemen Dan Organisasi, 6(1), 45-63.

Zeithaml, V. A., Bitner, M. J., \& Dwayned, D. G. (2012). Service Marketing Intregrating Customer Focus Across the Firm. McGraww-Hill. 